\title{
Assessment of the effects of land use pattern on distribution of sulphur fractions in soil
}

\author{
Dhaneshwar Padhan ${ }^{1 *}$, A. K. Pradhan ${ }^{2}$, Mahasweta Chakraborty ${ }^{1}$ and Arup Sen ${ }^{1}$ \\ ${ }^{1}$ Department of Agricultural Chemistry and Soil Science, Bidhan Chandra Krishi Viswavidyalaya, Mohanpur, \\ Nadia- 741235(West Bengal), INDIA \\ ${ }^{2}$ Department of Soil Science and Agricultural Chemistry, BAU, Sabour, Bhagalpur- 813210(Bihar), INDIA \\ *Corresponding author. E-mail: dhaneshwar.padhan@rediffmail.com
}

Received: September 12, 2015; Revised received: July 04, 2016; Accepted: August 27, 2016

\begin{abstract}
In the present investigation, various forms of sulphur (S) viz., total S, organic $S$, inorganic $S$ and available $S$ were estimated in soils under four different land uses viz., Rice-rice, rice-green gram, mango orchard and a fallow. Soils samples were taken up to a profile depth of $0.60 \mathrm{~m}$ at 3 depths i.e. $0-0.20 \mathrm{~m}, 0.20-0.40 \mathrm{~m}$ and $0.40-0.60 \mathrm{~m}$. The soils were found to be slightly acidic to moderately acidic in reaction (5.83-6.59), showing an increase along the depth irrespective of the land use pattern. Soil organic carbon (SOC) content (mean $5.5 \mathrm{gkg}^{-1}$ ) was found well above the low level of SOC in soils. Calcium carbonate content, bulk density and clay content of soils didn't maintain any definite pattern along the depth. All forms of $S$ were found to decrease along depth irrespective of the land use patterns. The available $S$ content ranged from 12.2 to $21.4 \mathrm{mgkg}^{-1}$ of soils. The relative preponderance of all the forms of $S$ followed the order: mango orchard> fallow $>$ rice-rice $>$ rice-green gram. On an average organic $S$ and available $S$ fractions constituted 93 and 6 per cent of total $S$ respectively. A correlation matrix revealed that all the forms of $\mathrm{S}$ maintained a significant positive correlation with SOC content while a negative correlation with $\mathrm{pH}$ of the soils. The results of the study will be useful in managing the different fractions of $S$ in soils in order to maintain its availability well above the critical level.
\end{abstract}

Keywords: Available S, Bulk density, Forms of S, Land use, SOC

\section{INTRODUCTION}

Sulphur is a highly reactive element present in many forms that play important biological and chemical functions in the environment (Reddy and De Laune, 2008). Sulphate-S is the most abundant form of inorganic $\mathrm{S}$ found in most of the soils and it is the form that the plants generally take up, although other reduced forms, such as elemental $\mathrm{S}$, thiosulphate and sulphide are important for anaerobic soils (Zhou et al., 2005). However, the bulk of soil S in natural and managed ecosystems is in organic form, which is directly affected by microbial activity through decomposition processes (Solomon et al., 2001). In aerobic agricultural soils, many microbial-mediated processes are responsible for $\mathrm{S}$ transformations, including mineralization, immobilization, and oxidation (Gahan and Schmalenberger, 2014). The knowledge of different forms of sulphur in soils together with their distribution in the root zone is of much relevance in assessing the sulphur supplying capacity of the soils. Its availability in soils is known to depend on physical and chemical properties viz., particle size, soil reaction, salt content and biomass (Balanagoudar and Satyanarayana, 1990; Misra et al., 1990; Ram et al., 1994). Physiography, through its influence on drainage, leach- ing and soil development also plays an important role in sulphur availability. Land use changes have a great influence on many soil physico-chemical properties mostly soil organic matter affecting its quality attributes and fertility. Land use practices affect the distribution and supply of soil nutrients by directly altering soil properties and by influencing biological transformations in the rooting zone (Murthy et al., 2002). Physical and chemical properties of the soils under continuous cultivation could vary from that under other land uses. Cultivated soils are poor in its fertility status as it has high bulk density, low total porosity, low pH and very low OM or organic carbon (OC) content (Diaz et al., 2005). Soil organic carbon (SOC) is a main factor affecting soil quality and agriculture sustainability. Being a source and sink of plant nutrients, SOC plays an important role in terrestrial C cycle (Freixo et al., 2002). Land use type has a deep effect on SOC storage, since it influences the amount and quality of litter input, litter decomposition rate, and stabilization of SOC and ultimately affecting the nutrient dynamics. Organic $\mathrm{S}$ is generally the most abundant form of $\mathrm{S}$ in agricultural soils with rapid fluxes between plant available inorganic and organic $S$ fractions (Janzen and Ellert, 1998). Therefore, differ- 
ent pools need to be assessed to evaluate soil S dynamics and the effects of plants on its availability.

Although inorganic sulphate generally makes up less than $5 \%$ of the sulphur present in agricultural soils, this does not mean that these soils contain limiting amounts of total sulphur. Most of the sulphur in soil $(>95 \%$ of total sulphur) is bound to organic molecules, and is therefore not directly plant-available. This organic sulphur is present as a heterogeneous mixture partly as microbial biomass or partly in the soil organic matter which needs to be converted to sulphate form prior to its uptake by plants. A number of studies have shown that organic $S$ contributes significantly to plant $S$ uptake through the process of mineralization (Blum et al., 2013) and as such the process of mineralization of organic $\mathrm{S}$ is mediated by a combination of microbial and enzyme (sulfatase) activities (Zhao et al., 1996). The changes in management practices imposed on agricultural lands and also the different land use pattern may influence such process (Janzen and Ellert, 1998). We may hypothesize that the various land use patterns may have an influence on the physic-chemical properties of soil and also on the transformation of various pools of sulphur along the soil depth which may form the basis for scheduling a sound fertilization program. In this backdrop, the objective of the present study was to investigate the effects of different land-use patterns on the amounts and forms of $\mathrm{S}$.

\section{MATERIALS AND METHODS}

Description of study area: The study was conducted in Saharapali village, located in Bargarh district of Odisha. The site is located at $21^{\circ} 33^{\prime} \mathrm{N}$ and $83^{\circ} 62^{\prime} \mathrm{E}$ which is $15 \mathrm{~km}$ away from the city. Four land uses were chosen for this study and these were Rice-Rice, Rice-Green gram, Mango orchard and Fallow belonging to the soil order Inceptisol. The annual rainfall of the area is around $1350 \mathrm{~mm}$ and the prevailing temperature around $30-35^{\circ} \mathrm{C}$.

Land use selection and soil sampling: Soil samples were collected from four land uses (Rice-rice, ricegreen gram, mango orchard and fallow lands) following standard protocols. Land use sites for taking soil samples were selected on the basis of cropping pattern followed and cultivation history. As per the history and management of selected land uses, the crop land has been under cultivation for more than 25 years. The mango orchard and fallow lands are also 30 years old. Representative sampling sites were selected randomly from each land use. Three representative units were selected from each land use and from each unit composite soil samples were collected from ten soil subsamples (points) with three depth i.e. 0-0.2, 0.2- 0.4 and $0.4-0.6 \mathrm{~m}$. The composite soil samples collected from representative land uses with three replications were air dried ground and passed through $0.5 \mathrm{~mm}$ sieve

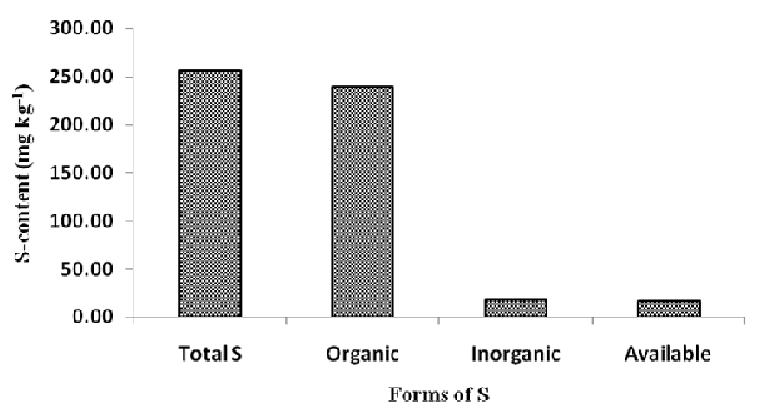

Fig. 1. Content of different forms of Sulphur in soils irrespective of land-use.

for organic carbon determination and $2 \mathrm{~mm}$ sieve for the analysis of other selected soil physic-chemical properties and different forms of S.

Soil analysis: Soil $\mathrm{pH}$ was measured in suspension of 1:2.5:: soil: water by the method as described by Jackson (1973). Oxidisable organic carbon of the soil samples were estimated by Walkley and Black method (1934) as described by Jackson (1973). Total sulphur was estimated by the method of acid digestion as described by Arkley (1961), inorganic $\mathrm{S}$ was determined by extracting the soils with $0.01 \mathrm{M} \mathrm{Ca}\left(\mathrm{H}_{2} \mathrm{PO}_{4}\right)_{2} \cdot 2 \mathrm{H}_{2} \mathrm{O}$ solution (Fox et al., 1964). Available $\mathrm{S}$ in the soil samples was determined by extracting soil with $0.15 \%$ $\mathrm{CaCl}_{2}$ solution (Williams and Steinberger, 1959). All the forms of $\mathrm{S}$ were estimated by developing turbidity with $\mathrm{BaCl}_{2}$ crystal (Chesnin and Yien, 1950). The organic $\mathrm{S}$ was calculated as the difference between the total S and inorganic S (Tabatabai and Bremner, 1972b).

Statistical analysis: Data were subjected to analysis of variance (ANOVA) with randomized block design using SAS software. Multiple correlation studies were also conducted among the soil parameters and different forms of $\mathrm{S}$.

\section{RESULTS AND DISCUSSION}

\section{Soil physic-chemical properties influenced by land use pattern}

Bulk density: The bulk density (BD) of the soils ranged from $1.31 \mathrm{Mg} / \mathrm{m} 3$ in the sub-surface $(0.4-0.6 \mathrm{~m})$ of mango orchard to $1.57 \mathrm{Mg} / \mathrm{m}^{3}$ in the mid-surface $(0.2-0.4 \mathrm{~m})$ of rice-green gram land use. Higher BD values were observed in all the three depths of soils of both rice-rice and rice-green gram land use. This could be possibly because of intensive cultivation usually followed in submerged rice cultivation which increases the penetration resistance and the $\mathrm{BD}$ values a whole. Whereas in case of mango orchard and fallow land use, the soils had comparatively lower BD values. Addition of organic matter results in improving the soil physical conditions making the soils more porous and well structured, which ultimately reduces the BD values. Cultivated lands tend to have higher soil bulk densities (Matano et al., 2015). 

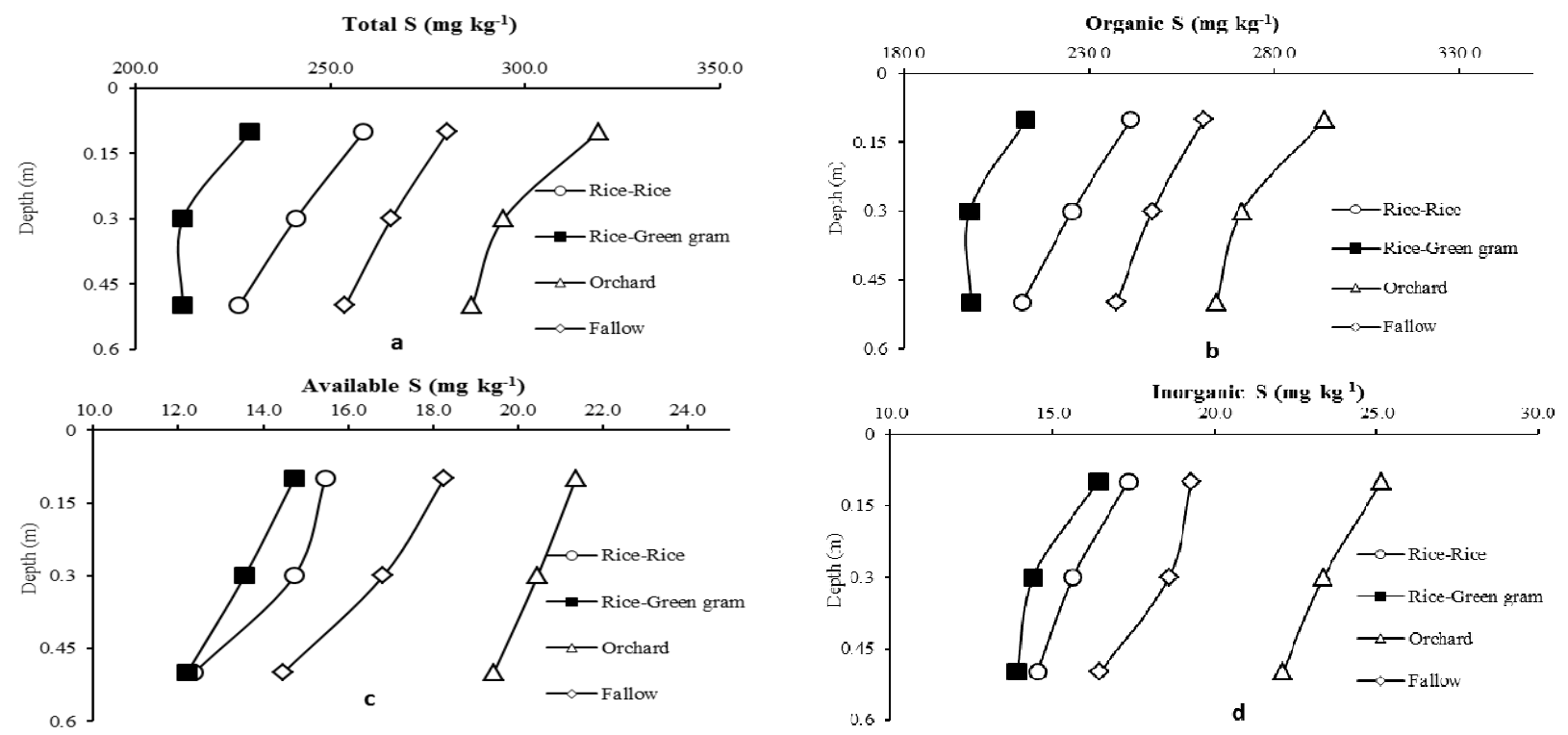

Fig. II. Depth-wise distribution of different forms of Sulphur under different land-use.

Soil pH: Soil pH was significantly $(\mathrm{P}<0.01)$ affected by the interaction of land use and soil depth, where the highest $\mathrm{pH}$ (6.6) was observed in the sub-surface layer (0.4- $0.6 \mathrm{~m})$ of fallow land and lowest on the surface layer $(0-0.2 \mathrm{~m})$ of orchard land use (Table 1$)$. It seems that the soils were slightly acidic to moderately acidic in nature. Both the surface and mid-surface soil layer of orchard land use had same $\mathrm{pH}$ value. In general an increase in $\mathrm{pH}$ of soil was noticed along the soil depth irrespective of the land use. This could be due to continuous removal of bases from the surface layer to lower layer through percolating water. Continuous removal of basic cations by harvested crops and animal grazing on the surface layer of cultivated and grazing land respectively may lower the soil $\mathrm{pH}$ (Habtamu et al., 2014). Comparatively lower $\mathrm{pH}$ values were observed in the mango orchard land use. This was because of the organic acids produced during the decomposition of fallen leaf litters. Such effects were more pronounced in the surface layer or to certain extent in the mid-surface soil layer than sub-surface soil layer.

Soil organic carbon: Soil organic carbon content was highly affected by the variation in land use pattern. Soil organic carbon content $\left(\mathrm{g} \mathrm{kg}^{-1}\right)$ ranged from 3.29.2 with mean of $5.5 \mathrm{~g} \mathrm{~kg}^{-1}$ of soil. It maintained highly significant correlation with all the forms of sulphur indicating its close association in the allocation of forms of $\mathrm{S}$ in soils (Table 2). The result was in line

Table 1. Physic-chemical parameters of soils under different land use patterns.

\begin{tabular}{lcccccc}
\hline Land use & $\begin{array}{c}\text { Depth } \\
(\mathbf{m})\end{array}$ & $\mathbf{p H}$ & $\begin{array}{c}\text { Organic carbon } \\
\left(\mathbf{g ~ k g}^{-\mathbf{1}}\right)\end{array}$ & $\begin{array}{c}\mathbf{C a C O}_{\mathbf{3}} \text { content } \\
\left(\mathbf{g ~ k g}^{-1}\right)\end{array}$ & $\begin{array}{c}\text { Bulk Density } \\
\left(\mathbf{g ~ c m}^{-\mathbf{3}}\right)\end{array}$ & $\begin{array}{c}\text { Clay content } \\
\left(\mathbf{g k g}^{-1}\right)\end{array}$ \\
\hline \multirow{3}{*}{ Rice-rice } & $0-0.2$ & 6.26 & 5.7 & 31.3 & 1.52 & 250 \\
& $0.2-0.4$ & 6.34 & 4.5 & 28.9 & 1.54 & 270 \\
& $0.4-0.6$ & 6.43 & 4.4 & 32.5 & 1.48 & 260 \\
Rice-green gram & $0-0.2$ & 6.06 & 4.8 & 28.9 & 1.47 & 230 \\
& $0.2-0.4$ & 6.19 & 3.4 & 27.5 & 1.57 & 220 \\
& $0.4-0.6$ & 6.33 & 3.2 & 29.6 & 1.51 & 210 \\
Mango orchard & $0-0.2$ & 5.83 & 9.2 & 25.6 & 1.39 & 2.42 \\
& $0.2-0.4$ & 5.83 & 8.6 & 29.4 & 1.31 & 220 \\
Fallow & $0.4-0.6$ & 6.04 & 6.9 & 26.3 & 1.48 & 210 \\
& $0-0.2$ & 6.08 & 6.1 & 30.3 & 1.49 & 1.47 \\
\hline ANOVA $p$-values & $0.2-0.4$ & 6.25 & 5.1 & 29.7 & & 200 \\
\hline Treatment & $0.4-0.6$ & 6.59 & 4.5 & 35.4 & $<0.01$ & $<0.01$ \\
Depth & & $<0.01$ & $<0.01$ & $<0.01$ & $<0.01$ & $<0.01$ \\
Treatment* Depth & & $<0.01$ & $<0.01$ & $<0.01$ & $<0.01$ & $<0.01$ \\
\hline
\end{tabular}

NS- Non significant 
with the findings of Habtamu et al., 2014 who reported strong relationship between SOC content and forms of sulphur. In general there was a decline in organic carbon content along the soil depth irrespective of the land use. The possible reason for such type of observation could be the lower recycling of organic residues in the lower layer and also owing to lower microbial activity. The mango orchard land use maintained significantly high amount of SOC as compared to other land use pattern. High amount of leaf litter or living biomass addition could be the reason for such type of observations.

Effect of land-use pattern on distribution of different forms of Sulphur along the soil depth

Total S:The total S contents ranged from $212.1 \mathrm{mg} \mathrm{kg}$ ${ }^{1}$ to $318.9 \mathrm{mg} \mathrm{kg}^{-1}$ of soil with a mean value of 256.6 $\mathrm{mg} \mathrm{kg}^{-1}$, the highest amount of total $\mathrm{S}$ being observed in the surface layer $(0-0.2 \mathrm{~m})$ of orchard plantation and lowest amount in the lower depth $(0.40-0.60 \mathrm{~m})$ of ricegreen gram land use. Almost similar amount of total $\mathrm{S}$ found in the mid-surface and lower surface of RiceGreen gram land use. The total S content of all the four land uses decreased along the soil depth (Fig. 2a). The decrease along the depth in all the four land uses was due to the decrease in organic carbon content indicating a close relationship between the organic carbon content and total S. Total S content was highly significantly correlated $(\mathrm{p}<0.01)$ with organic $\mathrm{S}(\mathrm{r}=0.99 * *)$, soil organic carbon $\left(\mathrm{r}=0.91^{* *}\right)$ indicating that most of the total $\mathrm{S}$ is in organic form (Table 2). Solomon et al. (2001) reported that bulk of the soil $S$ in natural and managed agro-ecosystem is in organic form. Wakney (2001) reported higher total S in the surface layer of virgin soil which decreased along soil depth due to lower organic matter content. The orchard plantation maintained higher amount of total S among all the land uses possibly because of the addition of enormous amount of organic matter due to leaf fall. The fallow land use also maintained higher amount of total S following the orchard plantation. Fallow land had a higher biomass addition without any perturbation which may lead to higher total $\mathrm{S}$ in such soils. Total amount of $\mathrm{S}$ in the soil decreased in order of Mango orchard $>$ fallow $>$ rice- rice> rice-green gram. A comparatively lower amount of total $S$ was found in the rice-green gram land use. The rice-rice land use added significant amount of organic matter maintaining higher total $\mathrm{S}$ content compared to rice-green gram land use. Intensive cultivation has resulted higher $\mathrm{S}$ removal and depletion in soil (Balsa et al., 1996).

Organic S: The major proportion of total $\mathrm{S}$ in most agricultural soils is present in organic forms (Janzen and Ellert, 1998; Saggar et al., 1998) mainly because, unlike inorganic $\mathrm{SO}_{4}{ }^{2-}-\mathrm{S}$, soil organic $\mathrm{S}$ is mostly insoluble in water and not susceptible to leaching losses. Organic $\mathrm{S}$ is also the dominant $\mathrm{S}$ pool in the upper 10 $\mathrm{cm}$ of these tropical soils. Its amount varied from 197.8 $\mathrm{mg} \mathrm{kg}^{-1}$ in the mid-surface $(0.2-0.4 \mathrm{~m})$ of rice-green gram land use to $293.7 \mathrm{mg} \mathrm{kg}^{-1}$ soil in the surface of mango orchard land use. Organic S constituted $93 \%$ of the total S. The percentage of organic $\mathrm{S}$ in these soils is of similar magnitude as those quoted by Solomon et al., 2001 who reported organic S constitute $95 \%$ of total $\mathrm{S}$ in natural and managed agro-ecosystem. The organic S content followed the trend of organic carbon content of the soil signifying organic $S$ content is a function of organic matter content of the soil. Probert (1980) reported similar results that the profile of organic S content generally follows the pattern of organic carbon content in soils with soil depth. Table 2 shows that organic $\mathrm{S}$ was highly and significantly correlated with SOC $(\mathrm{r}=0.91 * *)$ indicating close relationship between the two. Padhan (2014) reported strong relationship between SOC and organic $\mathrm{S}$ in soils of some long-term experiments. The close association of organic S with SOC in soil is due to the fact that SOM (soil organic matter) provides the major non- leachable reserve of S. SOM content could be taken as a fair indicator of the $\mathrm{S}$ status in the soils (Solomon et al., 2001). The higher content of organic $S$ in surface layer of orchard was due to higher addition of biomass. The fallow land use showed similar amounts of organic $S$ possibly because of addition of grass residues without subsequent exposure for oxidation of organic matter. However, in rice-rice and rice-green gram land uses, the organic sulphur content declined due to prolonged cultivation. Habtamu et al. (2014) also reported decreasing trend of organic $S$ content along the soil depth. The former maintained comparatively higher amount due to higher biomass addition than the latter.

Available S: The available S content of soil is a function of mineralization of organic S. Mineralization of organic $\mathrm{S}$ depends upon many factors and it varies from land use to land use and also the type of crop

Table 2. Correlation matrix between $\mathrm{pH}$, organic carbon and different forms of sulphur.

\begin{tabular}{lllllll}
\hline & $\mathbf{p H}$ & Organic Carbon & Total S & Organic S & Available S & Inorganic S \\
\hline $\mathrm{pH}$ & 1 & & & & & \\
Organic Carbon & $-0.758^{* *}$ & 1 & & & & \\
Total S & $-0.630^{* *}$ & $0.919^{* *}$ & 1 & & & \\
Organic S & $-0.608^{* *}$ & $0.910^{* *}$ & $0.999^{* *}$ & 1 & & \\
Available S & $-0.794^{* *}$ & $0.922^{* *}$ & $0.943^{* *}$ & $0.934^{* *}$ & 1 & \\
Inorganic S & $-0.778^{* *}$ & $0.945^{* *}$ & $0.951^{* *}$ & $0.939^{* *}$ & $0.971^{* *}$ & 1 \\
\hline
\end{tabular}

**Correlation is significant at the 0.01 level 
species in a particular land use. The highest amount of available $\mathrm{S}$ was noticed in the surface layer of orchard soil and the lowest amount in the lower depth (0.4$0.6 \mathrm{~m}$ ) of rice-green gram land use (Fig. 2c). The highest availability of $S$ in orchard land use was due to higher mineralization of organic $\mathrm{S}$ as the microbial activity in this case is more pronounced owing to higher biomass addition. This also revealed that the orchard land use is more efficient in mineralizing the organic $\mathrm{S}$ to inorganic sulphate among all the land uses. The available $\mathrm{S}$ content in rice-rice and ricegreen gram land use was lower because continuous cropping removed greater amount of S. Intensive cultivation results higher $S$ removal and depletion in soil (Balsa et al., 1996). Irrespective of all the four land uses, the available $\mathrm{S}$ content declined along the depth (Fig. 2c). The possible reason for such type of occurrence may be due to lower rate of mineralization in the lower depth owing to slower microbial activity because of lack of carbon source and aeration status compared to surface where microbial activity is more pronounced than the former. Available $\mathrm{S}$ was significantly and positively correlated with SOC content and showed significant negative correlation with the $\mathrm{pH}$ of soils. This positive correlation with SOC content revealed that available $S$ content in soil is a function of organic matter content of the soil. These results are in accordance with those of Kotur and Jalali (2008), Basumatary et al., 2010 and Javed et al., 2014. They reported strong positive relationship of available $\mathrm{S}$ with SOC content indicating SOC is the regulating factor for availability of $\mathrm{S}$ in soil. Available $\mathrm{S}$ existed in a state of dynamic equilibrium with other forms of $S$ which can be evident from the significant positive correlation with all forms of S (Table 2). Sharma and Jaggi (2001) and Javed et al. (2014) reported significant positive correlation among the different forms of $\mathrm{S}$.

Inorganic $\mathbf{S}$ : Sulphate $\left(\mathrm{SO}_{4}{ }^{2-}\right)$ is the main inorganic form of $\mathrm{S}$ present in most soils, although some reduced $\mathrm{S}$ forms (e.g., elemental $\mathrm{S}$, thiosulfate or sulfide) may be present in soils under predominantly anaerobic conditions (Biederbeck, 1978; Kowalenko, 1993a). Since the reduced $\mathrm{S}$ forms are transitory in aerobic soils and their concentrations are usually negligible (Biederbeck, 1978; Janzen and Ellert, 1998), in the present study inorganic $\mathrm{S}$ was estimated from the solution and adsorbed $\mathrm{SO}_{4}{ }^{2-}$. The inorganic $\mathrm{S}$ mainly occurs in form of sulphate-sulphur which is readily available to plants. But certain amount of sulphur that is co-precipitated with calcium or barium carbonate constitutes a significant fraction of inorganic $\mathrm{S}$. The inorganic $\mathrm{SO}_{4}{ }^{2-}$ ranged from $13.9 \mathrm{mg} \mathrm{kg}^{-1}$ to $25.2 \mathrm{mg} \mathrm{kg}^{-1}$ soil with mean value of $18.1 \mathrm{mg} \mathrm{kg}^{-1}$ of soil. On an average it constituted $7.0 \%$ of the total $\mathrm{S}$ content of soil. The inorganic $\mathrm{S}$ showed a depth-wise decrease along the soil profile (Fig. 2d). The decrease is more pronounced in the rice-green gram land use. This decrease may be due to continuous cropping without addition of $\mathrm{S}$ from external sources. The orchard and fallow land uses maintained higher amount of inorganic $\mathrm{S}$ due to higher rate of mineralization having pronounced microbial activities.

Correlation between $\mathbf{p H}$, organic carbon and different forms of sulphur: Forms of sulphur showed significant correlation with $\mathrm{pH}$ and soil organic carbon (SOC) content of soil. All the forms of S (total S, organic $\mathrm{S}$, inorganic $\mathrm{S}$ and available $\mathrm{S}$ ) and SOC showed significant negative correlation with $\mathrm{pH}$ of the soil. Soil organic carbon maintained significant positive correlation with all forms of S. Das et al. (2011) and Dhamak et al. (2014) also reported significant positive correlation of SOC with different forms of $\mathrm{S}$. The negative relationship between $\mathrm{pH}$ and forms of $\mathrm{S}$ may be due to the presence of $\mathrm{H}^{+}$and $\mathrm{OH}^{-}$in the soil complex which binds the $\mathrm{SO}_{4}{ }^{2-}$ ions rendering it unavailable (Borkotoki and Das, 2008). Total S maintained significant positive correlation with all forms of $\mathrm{S}$ indicating a state of dynamic equilibrium in the soil. Similar positive relationship among various forms of sulphur was earlier reported by Tripathi et al., (2000); Das et al., (2012) and Javed et al., (2014). Correlation studies (Table 2) indicated that organic S maintained a high significant correlation with SOC content indicating that SOC is the main source of organic S. Reports were there also regarding the strong association of organic $S$ and SOC content of soils (Borkotoki and Das, 2008; Javed et al., 2014 and Dhamak et al., 2014).

\section{Conclusion}

All the four land-use patterns considered in the present study showed a significant depletion in content of forms of S with soil depth. The reduction is associated with a decline in organic carbon content of the soil. Organic $S$ was the dominant $S$ fraction constituting the highest proportion of total S. Soils of mango orchard and fallow land use maintained a higher content for all the forms of S compared to the rice-rice and rice-green gram system. Thus it can be concluded that sulphur availability is a function of soil organic matter (SOM) content and $\mathrm{pH}$, and is highly influenced by the land use patterns. If the current rate of organic matter depletion and man-made perturbation continues, widespread $S$ deficiency might occur in the near future, since SOM is a major source of S. Measures have to be designed for replenishment and subsequent maintenance of soil $\mathrm{S}$ stock, to ensure sustainable crop production and maintain the available $S$ status of soil above the critical limit for a longer period of time.

\section{ACKNOWLEDGEMENTS}

The corresponding author wishes to acknowledge the coauthors for their continuous help in preparing this manuscript and also for their help during the course of this study. 


\section{REFERENCES}

Arkley, T.H. (1961). Sulphur compounds of soil systems. Ph.D. Dissertation University of California, Berkley.

Balanagoudar, S.R. and Satyanarayana, T. (1990). Depth distribution of different forms of Sulphur in Vertisols and Alfisols. Journal Indian Society of Soil Science. 38: 634-640.

Balsa, M.E., Serrao, M.G., Martins, M.M., Castelo-Branco, M.A., Gusmao, M.R. and Fernandes, M.L. (1996). Effects of Pyrite Residue Amendment on Sulfur Availability in a Calcareous Soil Cropped with Sown Pasture in Fertilizers and Environment C. Rodriguez-Barrueco, editor. Kluwer academic Publ., Printed in the Netherlands. pp 453-455.

Basumatary, A., Das, K.N. an Borkotoki, B. (2010). Interrelationships of sulpur with soil properties and its availability index in some rapessed-growing Inceptisols of Assam. Journal of the Indian Society of Soil Science. 58:394-402.

Biederbeck, V.O. (1978). Soil organic sulfur and fertility. In: Schnitzer, M., Khan, S.M. ŽEds.., Soil Organic Matter. Elsevier, Amsterdam, pp. 273-310.

Blum, S. Ch., Lehmann, J., Solomon, D., Caires, E.F. and Alleon, L.R.F. (2013). Sulfur forms in organic substrates affecting $\mathrm{S}$ mineralization in soil. Geoderma.200 -201: 156-164. DOI: http://dx.doi.org/10.1016/ j.geoderma.2013.02.003.

Borkotoki, B. and Das, K.N. (2008). Forms of sulphur and their relationship with soil roperties in Entisols, Inceptisols and Alfisols of Assam. Journal of the Indian Society of Soil Science. 56:186-191.

Chesnin, L. and Yien, C.H. (1950). Turbidimetric determination of available sulphates. Soil Science Society of America Proceedings. 15: 149-151.

Das, K.N., Basumatari, A. and Borkotoki, B. (2012). Forms of sulphur in some rapeseed-growing soils of Assam. Journal of the Indian Society of Soil Science. 60: 13 19.

Das, K.N., Basumatary, A. and Borkotoki, B. (2011). Interrelationship of forms of sulphur with its availability indices and soil properties in Entisols of Assam. Journal of the Indian Society of Soil Science. 59:134-140.

Dhamak, A.L., Meshram, N.A. and Waikar, S.L. (2014). Comparative Studies on Dynamics Soil Properties and Forms of Sulphur in Oilseed Growing Soils of Ambajogai Tahsil of Beed District. IOSR Journal of Agriculture and Veterinary Science. 7(12):98-102.

Fox, R.L., Olsen, R.A. and Rhoades, H.F. (1964). Evaluation of sulfur status of soils by plant and soil tests. Soil Science Society of America Proceedings. 28: 243-246.

Freixo, A.A., Machado, P.L., Santos, H.P., Silva, C.A. and Fadigas, F.S. (2002). Soil organic carbon and fractions of a Rhodic Ferralsol under the influence of tillage and crop rotation systems in southern Brazil. Soil \& Tillage Research. 64:221-230.

Gahan, J. and Schmalenberger, A. (2014). The role of bacteria and mycorrhiza in plant sulfur supply. Frontier in Plant Science.5 (723): 1-7.

Habtamu, A., Heluf, G., Bobe, B. and Enyew, A. (2014). Fertility Status of Soils under Different Land uses at Wujiraba Watershed, North-Western Highlands of Ethiopia. Agriculture, Forestry and Fisheries. 3(5):410-
419.

Jackson, M.L. (1973). Soil chemical Analysis. Prentice Hall of India Private Limited, New Delhi.

Janzen, H.H. and Ellert, B.H. (1998). Sulfur dynamics in cultivated temperate agroecosystems. In: Maynard, D.G. ŽEd.., Sulfur in the Environment. Dekker, New York, pp. 11-43.

Javed, A., Sandeep. S. and Katiyar, D.K. (2014). Forms of sulphur in Wheat growing soils of Agra district of Uttar Pradesh. Annals of Plant and Soil Research. 16(2): 148150.

Kotur, S. and Jalali, V.K. (2008). Forms of sulphur and their relationship in soils of different agro climatic zones of Jammu region. Journal of the Indian Society of Soil Science. 56: $306-312$.

Kowalenko, C.G. (1993a). Extraction of available sulfur. In: Carter, M.R. ŽEd.., Soil Sampling and Methods of Analysis. Lewis Pub., Boca Raton, FL, pp. 65-74.

Matano, A.S., Kanangire, C.K., Anyona, D.N., Abuom, P.O., Gelder, F.B., Dida, G.O., Owuor, P.O. and Ofulla, A.V.O. (2015). Effects of Land Use Change on Land Degradation Reflected by Soil Properties along Mara River, Kenya and Tanzania. Open Journal of Soil Science. 5: 20-38.

Misra, U.K., Das, C.P. and Mitra, G.N. (1990). Forms of sulphur in some soils of Orissa in relation to relevant soil' properties. Journal of Indian Society of Soil Science. 38: 61-69.

Murthy, D., Kirschbaum, M.U.F., McMurtrie, R.E. and McGilvray, H. (2002). Does conversion of forest to agricultural land change soil carbon and nitrogen? A review of the literature. Global Change Biology. 8: 105 -123 .

Padhan, D. (2014). Sulphur fractions in soils of long-term experiments with various management practices and cropping systems under different agro-ecological zones of India. M.Sc Thesis pp. 1-70.

Probert, M.E. (1980. Sulfur in Australia". In: Freney JR, Nicholson AJ (eds), Australian Academy of Science, Canberra. pp. 158-169.

R Diaz, M., Buenob, J., Gonza'lez-Prietoa, S.J. and Carballasa, T. (2005). Cultivation effects on biochemical properties, $\mathrm{C}$ storage and $15 \mathrm{~N}$ natural abundance in the $0-5$ $\mathrm{cm}$ layer of an acidic soil from temperate humid zone. Soil and Tillage Research.84: 216-221.

Ram, M. and Diwedi, K.N. (1994). Delineation of sulphur deficient soil groups in central alluvial tract of Uttar Pradesh. Journal of Indian Society of Soil Science. 42: 284-286.

Reddy, K.R. and DeLaune, R.D. (2008). Biogeochemistry of Wetlands: Science and Applications. CRC Press, Boca Raton, FL. pp. 447-454.

Saggar, S., Hedley, M.J.and Phimsarn, S. (1998). Dynamics of Sulfur transformations in grazed pastures. In: Maynard, D.G. ŽEd.., Sulfur in the Environment. Dekker, New York, pp. 45-94.

Sharma, R.K. and Jaggi, R.C. (2001). Relationships of forms and availability indices of sulphur with properties of soils of Kangra, Himachal Pradesh. Journal of the Indian Society of Soil Science. 49: 698 - 702.

Solomon, D., Lehmann, J., Tekalign, M., Fritzsche, F. and Zech, W. (2001). Sulfur fractions in particle-size separates of the sub-humid Ethiopian highlands as influ- 
enced by land use changes. Geoderma. 102:41-59.

Tabatabai, M.A. and Bremner, J.M. (1972b). Forms of sulfur, and carbon, nitrogen, sulfur relationship, in Iowa soils. Soil Science. 114:380-386.

Tripathi, S.B., Singh, R.S. and Tripathi, S.K. (2000). Distribution of sulphur in Ustrochrepts under cultivation of fodder and natural grass cover. Journal of the Indian Society of Soil Science. 48: 608-611.

Wakney, N.C. (2001). Assessment of Important Physicochemical Properties of Nitosols under Different Management Systems in Bako area, Western Ethiopia. (M.Sc. thesis), Alemay University, Ethiopia.

Walkley, A. and Black, C.A. (1934). An examination of different methods for determining soil organic matter and the proposed modification by the chromic acid titration method. Soil Science. 37: 29-38.

Williams, C.H. and Steinbergs, A. (1959). Soil sulphur fractions and chemical indices of available sulphur in some Australian soils. Australian Journal of Agricultural Research. 10: 340-352.

Zhao, F.J., Wu, J. and McGrath, S.P. (1996). Soil organic sulphur and its turnover. In A. Piccolo (Ed.), Humic Substances in Terrestrial Ecosystems. Amsterdam: Elsevier. pp. 467-506.

Zhou, W., He, P., Li, S. and Lin, B. (2005). Mineralization of organic sulfur in paddy soils under flooded conditions and its availability to plants. Geoderma. 125:85-93. 